\title{
Morphological aspects in remineralizing potential of Silver Diamine Fluoride
}

\author{
LAURA IdDORAŞI ${ }^{1)}$, EMANUELA LIDIA CRĂCIUNESCU ${ }^{1,2)}$, AdRIAN TUdOR STAN ${ }^{1,2)}$, COSMIN SineSCU ${ }^{1,2)}$,

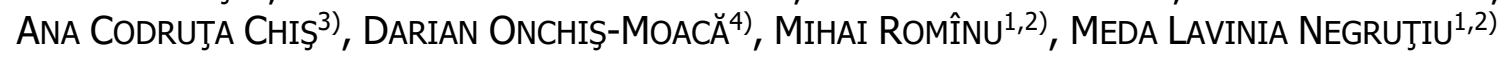 \\ 1) Department of Prostheses Technology and Dental Materials, Faculty of Dental Medicine, Victor Babeş University of Medicine \\ and Pharmacy, Timişoara, Romania \\ 2) Research Center in Dental Medicine Using Conventional and Alternative Technologies, Timişoara, Romania \\ 3) Research Institute for Biosafety and Bioengineering, Faculty of Agriculture, King Michael I of Romania Banat University \\ of Agricultural Sciences and Veterinary Medicine, Timişoara, Romania \\ ${ }^{4)}$ Signal, Image and Machine Learning Team, Department of Computer Science, West University of Timişoara, Romania
}

\begin{abstract}
Objectives: The purpose of this study was to demonstrate the efficacy of Silver Diamine Fluoride (SDF) antibacterial solution in penetrating the demineralized areas of enamel. Materials and Methods: It was considered a group of four extracted teeth (with no color fading, fissures, decay, or demineralization). Each tooth was sectioned in two equal parts, in mesio-distal direction, using a dental handpiece and a special rounded, flat bur. Each specimen was demineralized, for one minute, with $45 \%$ orthophosphoric acid, on occlusal and proximal zones. The specimens were then washed and dried with water-air dental syringe. All the probes were inspected with an optical microscope and enamel thickness was digitally measured. Advantage Arrest (Elevate Oral Care, USA), which contains SDF, was applied on the previous demineralized zones. The penetration of the substance was visually inspected with the optical microscope and electronically measured. Results: It was observed an improvement in remineralizing the white spots on enamel surfaces, the optical microscope being able to detect both demineralization and the penetration of SDF through enamel. Conclusions: Based on our in vitro study, SDF (Advantage Arrest) was capable to induce/increase enamel remineralization, through SDF penetration.
\end{abstract}

Keywords: silver nanoparticles, white spot lesions, enamel remineralization, Silver Diamine Fluoride penetration, antibacterial activity.

\section{口 Introduction}

The most prevalent diseases of the oral cavity are the carious lesions. They occur due to the demineralization of tooth's fissures or plain surfaces. The intense action of the organic acids causes the demineralization, with those organic acids originating from fermentation of carbohydrates and degradation of the organic matrix [1].

Speaking in terms of morphology, teeth have a complex structure consisting of enamel, pulp-dentin complex, and cementum. Enamel formation is made by specific cells called ameloblasts, which originate from ectoderm. Enamel's role is to cover the anatomic crowns of teeth, varying in thickness depending on the area in which is located; it is averaging $2 \mathrm{~mm}$ at the incisal edge of the frontal teeth, $2.3-2.5 \mathrm{~mm}$ at the premolars' cusps and maximum $3 \mathrm{~mm}$ at molars' cusps. The cusps of posterior teeth have different mineralization centers, forming lobs that converge together. In some areas, the coalescence may not be complete, resulting in pits and fissures that have enamel reduced in thickness. Simultaneously, the enamel on smooth surfaces, such as proximal areas, has a decreased thickness $(0.872 \mathrm{~mm}$ to $1.015 \mathrm{~mm}$ ) [2].

Dentin represents the largest portion of a tooth, being in percent of $70 \%$ mineralized, with an organic content calculating for $20 \%$ of the matrix and a $10 \%$ of water.
The physical characteristics of teeth are mainly attributed to enamel. It is also believed that collagen performs as an active, safeguarding protein of the underlying hydroxyapatite (HA) crystallite frame. There are two types of collagen. Type I collagen is known as procollagen, being secreted from cells (fibroblasts, odontoblasts, osteoblasts) into the extracellular gaps. In those gaps is type I collagen converted into tropocollagen. Tropocollagen can selfassemble into fibrils, which are built from the undulate packing of the individual collagen molecules. In dentin, type I collagen gets about $56 \%$ of mineral in its fibrils' pores. Dentin matrix protein-1 initiates the nucleation and modulation of mineral phase's morphology. During dentinogenesis, there exist three types of mineralization: "matrix vesicle-derived mineralization (in mantle dentin), molecule-derived mineralization - ECM (in majority of dentin), and blood serum-derived mineralization (in peritubular dentin)" [2-4].

In enamel, after the dentin mineralization at dentinoenamel junction (DEJ) was initiated, ameloblast cells will start to secrete enamel matrix proteins: ameloblastin, amelogenin, enamelin and proteinases at the dentin surface, being responsible for a prompt mineralization of $\sim 30 \%$ of enamel. The ribbons (first formed enamel crystals) expand between the existing dentin crystal and elongate at the mineralization front where enamel proteins have been

This is an open-access article distributed under the terms of a Creative Commons Attribution-NonCommercial-ShareAlike 4.0 International Public License, which permits unrestricted use, adaptation, distribution and reproduction in any medium, non-commercially, provided the new creations are licensed under identical terms as the original work and the original work is properly cited. 
developed. Meanwhile, the ameloblast start secreting huge quantities of enamel matrix proteins. In the moment in which the whole thickness of enamel is formed, the ameloblasts start becoming "protein-resorbing" cells. The mineral content will be slowly diminished from the enamel outer toward the DEJ $[4,5]$.

The dynamic process of demineralization may be reversed if the white spot lesions are detected in early stages. Caries progression appears when there is a demineralization-remineralization imbalance. While the demineralization progresses, one or more white spots appear due to enamel continue mineral privation. This fact causes visual changes which start with the subclinical stage (white spots) and followed by cavitation [1].

There have been massive searches trying to find the best options for detection of early signs of caries lesions and their treatment. As treatment, all the existent substances try to enhance the enamel's remineralization (for white spots lesions) or dentin disinfection for profound lesions.

Some authors showed, in a systematic review (2017), that the remineralizing agents, such as casein phosphopeptides along amorphous calcium phosphate (CPP-ACP), casein phosphopeptides including amorphous calcium phosphate and fluoride (CPP-ACFP), Icon (DMG ChemischPharmazeutische Fabrik GmbH, Hamburg, Germany) can induce regression of white spots lesions, in size and their visual appearance, improving esthetics at the same time [6].

Other authors evaluated, in comparison, the capacity of a sealant and an infiltrant of penetrating the fissure caries lesions. They mentioned that the infiltrant was developed for proximal lesions and the "resin infiltration technique" has not been evaluated for fissures lesions. The study revealed that the resin infiltration was much more efficient than the fissure sealing $[7,8]$.

Other studies demonstrated that silver nanoparticles (AgNPs) can inhibit the deoxyribonucleic acid (DNA) replication of bacteria, when remaining in contact with $\mathrm{Ag}^{+}$ions and major structural changes in the bacteria's membrane. "The bactericidal effect of AgNPs is size dependent, so that AgNPs mainly in the range of 1-10 nm attach better to the cell's membrane surface, disturbing the main functions. They are possibly able to interact with sulfur- and phosphorus-containing compounds, such as DNA, having a great contribution to the bactericidal effect". Accordingly, the AgNPs having dimensions from $2 \mathrm{~nm}$ to $5 \mathrm{~nm}$ are capable to penetrate the dentinal tubules and to inactivate the bacteria's metabolism. The incorporation of AgNPs in dental materials may be as a monomer, usually 2-(tert-Butylamino)ethyl methacrylate, for improving the Ag solubility in the resin solution, such a product being Advantage Arrest (Elevate Oral Care, USA), which contains SDF [9].

\section{Aim}

This study aimed to evaluate, in comparison, the efficacy of Advantage Arrest in penetrating the tooth's structure, in two different morphological areas: the proximal and the occlusal fissures.

\section{a Materials and Methods}

Four extracted teeth, with no discoloration, carious lesions or demineralization were selected and maintained in physiological serum. Each tooth was sectioned in two equal parts, in mesio-distal direction, as shown in Figure 1, resulting eight specimens. A demineralization agent, $45 \%$ orthophosphoric acid, was applied on each sample and maintained for one minute, on two different enamel areas: occlusal and proximal. The agent was then washed out and the sample dried with water-air dental syringe, as it can be observed in Figure 1. The final step consisted of visually and digital, optical microscope inspection and the enamel thickness was electronically measured (Figure 2).

Advantage Arrest (Elevate Oral Care, USA) (Figure 3) has been applied on both demineralized areas, proximal and occlusal, without touching the inner surface of the teeth.

The specimens have been inspected with optical, digital microscope (Figure 4), with a focus range of $0-40 \mathrm{~mm}$, a still image capture resolution of $160 \times 120,320 \times 340$, $640 \times 480,1280 \times 1024,1600 \times 1200$ pixels, digital zoom of $5 \times$ and sequence mode and magnification ratio of $20 \times-$ $800 \times$.

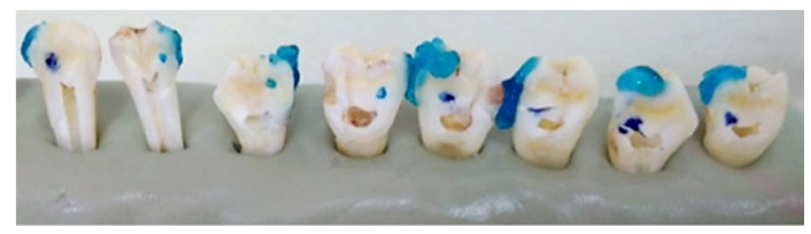

Figure 1 - Four extracted teeth, sectioned in mesiodistal direction - eight specimens.

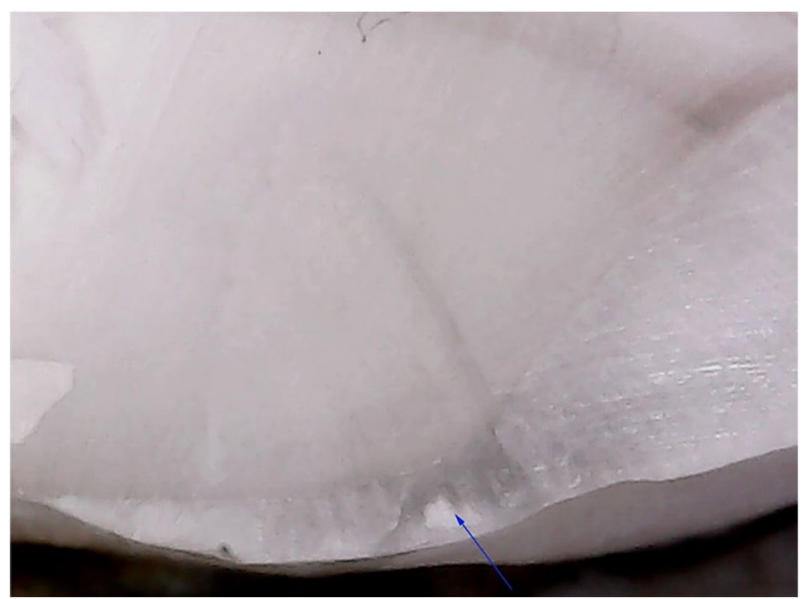

Figure 2 - The proximal, demineralized area of one of the specimens viewed on optical microscope.

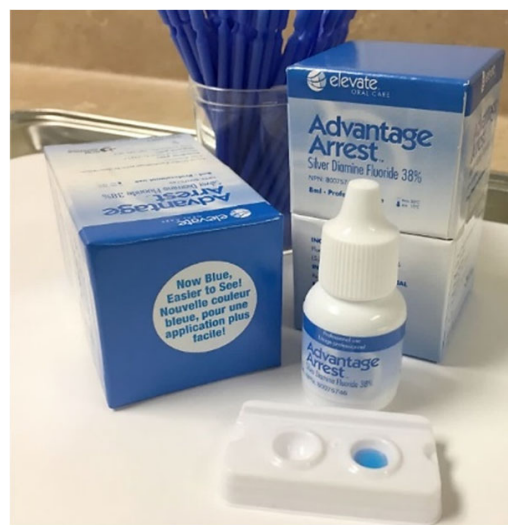

Figure 3 - Advantage Arrest product [9].

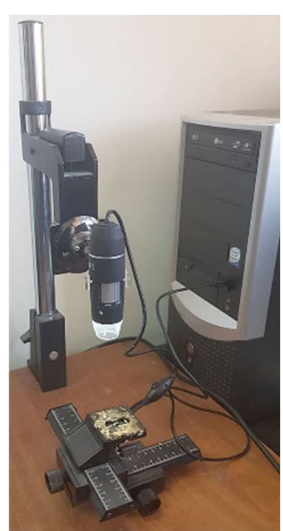

Figure 4-Optical microscope used in the study.
For the statistical analysis, we apply first the nonparametric Mann-Whitney-Wilcoxon analysis $[10,11]$ to 
decide whether the population disseminations are identical without charging them to follow the normal distribution. In the data frame list named SDF penetration, we gather all the values measured after SDF penetration, meanwhile another data column indicates the area type $(0-$ proximal, 1 - occlusal). In other words, the differentiating factor is the area type. Without supposing that the data has normal distribution, we need to set at $\alpha=0.05$ significance level if the SDF penetration data of proximal and occlusal area have identical data distribution.

To apply an analysis of variance (ANOVA)-like test, which for the case of only two columns is identical with the $t$-test, we first try to correct the lack of normal distribution. Parametric methods, such as $t$-test and ANOVA tests [12] to be meaningful, they assume the dependent variable as approximately normally distributed for every group to be compared.
In addition, statistical analysis has been done using the IBM Statistical Package for the Social Sciences (SPSS) software. It considered elements of descriptive statistics, Box-Plot diagrams, and the $t$-test for the studied variables.

\section{口 Results}

It was observed a possible improvement in remineralizing of the white spots on flat and occlusal surfaces, the optical microscope detecting the demineralization and the penetration of the Advantage Arrest through enamel. The areas of demineralization and SDF penetration were measured (in four different points) with the TAGARNO measurement software provided by the digital microscope. The values have been collected and compared in Table 1. It has been detected a remineralization percentage of $52.675 \%$ for proximal areas and of $41.001 \%$ for occlusal areas.

Table 1 - The values recorded for each area of demineralization, SDF penetration and average percentage of SDF penetration

\begin{tabular}{|c|c|c|c|c|c|c|}
\hline \multirow{2}{*}{$\begin{array}{l}\text { Specimen } \\
\text { No. }\end{array}$} & \multicolumn{3}{|c|}{ Proximal area } & \multicolumn{3}{|c|}{ Occlusal area } \\
\hline & $\begin{array}{c}\text { Demineralization } \\
{[\mathrm{mm}]}\end{array}$ & $\begin{array}{c}\text { Remineralization } \\
{[\mathrm{mm}]}\end{array}$ & $\begin{array}{c}\text { Remineralization } \\
{[\%]}\end{array}$ & $\begin{array}{c}\text { Demineralization } \\
\text { [mm] }\end{array}$ & $\begin{array}{c}\text { Remineralization } \\
{[\mathrm{mm}]}\end{array}$ & $\begin{array}{c}\text { Remineralization } \\
{[\%]}\end{array}$ \\
\hline \multirow{4}{*}{1.} & 0.356 & 0.163 & 45.787 & 0.560 & 0.145 & 25.893 \\
\hline & 0.283 & 0.268 & 94.700 & 0.430 & 0.110 & 25.581 \\
\hline & 0.430 & 0.179 & 41.628 & 0.520 & 0.130 & 25.000 \\
\hline & 0.520 & 0.083 & 15.962 & 0.250 & 0.070 & 28.000 \\
\hline \multirow{4}{*}{2.} & 0.131 & 0.113 & 86.260 & 0.163 & 0.079 & 48.466 \\
\hline & 0.137 & 0.106 & 77.372 & 0.270 & 0.171 & 63.333 \\
\hline & 0.211 & 0.151 & 71.564 & 0.304 & 0.208 & 68.421 \\
\hline & 0.344 & 0.090 & 26.163 & 0.275 & 0.127 & 46.182 \\
\hline \multirow{4}{*}{3.} & 0.247 & 0.233 & 94.332 & 0.437 & 0.312 & 71.396 \\
\hline & 0.438 & 0.311 & 71.005 & 0.538 & 0.159 & 29.554 \\
\hline & 0.489 & 0.333 & 68.098 & 0.532 & 0.210 & 39.474 \\
\hline & 0.512 & 0.433 & 84.570 & 0.525 & 0.427 & 81.333 \\
\hline \multirow{4}{*}{4.} & 0.289 & 0.245 & 84.775 & 0.249 & 0.070 & 28.112 \\
\hline & 0.356 & 0.185 & 51.966 & 0.481 & 0.124 & 25.780 \\
\hline & 0.237 & 0.067 & 28.270 & 0.524 & 0.282 & 53.817 \\
\hline & 0.193 & 0.112 & 58.031 & 0.442 & 0.296 & 66.968 \\
\hline \multirow{4}{*}{5.} & 0.237 & 0.144 & 60.759 & 0.453 & 0.347 & 76.600 \\
\hline & 0.348 & 0.215 & 61.782 & 0.406 & 0.296 & 72.906 \\
\hline & 0.400 & 0.222 & 55.500 & 0.292 & 0.136 & 46.575 \\
\hline & 0.357 & 0.097 & 27.171 & 0.262 & 0.183 & 69.847 \\
\hline \multirow{4}{*}{6.} & 0.076 & 0.052 & 68.421 & 0.373 & 0.234 & 62.735 \\
\hline & 0.146 & 0.126 & 86.301 & 0.399 & 0.171 & 42.857 \\
\hline & 0.452 & 0.289 & 63.938 & 0.248 & 0.203 & 81.855 \\
\hline & 0.553 & 0.378 & 68.354 & 0.398 & 0.223 & 56.030 \\
\hline \multirow{4}{*}{7.} & 0.191 & 0.179 & 93.717 & 0.454 & 0.428 & 94.273 \\
\hline & 0.286 & 0.219 & 76.573 & 0.551 & 0.327 & 59.347 \\
\hline & 0.282 & 0.245 & 86.879 & 0.647 & 0.267 & 41.267 \\
\hline & 0.372 & 0.193 & 51.882 & 0.411 & 0.166 & 40.389 \\
\hline \multirow{5}{*}{8.} & 0.106 & 0.092 & 86.792 & 0.234 & 0.169 & 72.222 \\
\hline & 0.187 & 0.162 & 86.631 & 0.365 & 0.139 & 38.082 \\
\hline & 0.234 & 0.171 & 73.077 & 0.330 & 0.093 & 28.182 \\
\hline & 0.252 & 0.148 & 58.730 & 0.142 & 0.042 & 29.577 \\
\hline & & $\begin{array}{c}\text { Proximal } \\
\text { remineralization }\end{array}$ & 52.675 & & $\begin{array}{c}\text { Occlusal } \\
\text { remineralization }\end{array}$ & 41.001 \\
\hline
\end{tabular}

SDF: Silver Diamine Fluoride.

\section{Statistical analysis}

The null hypothesis is that the SDF penetration values for proximal and occlusal areas are equivalent populations.
To test this hypothesis, we applied the test to compare the independent samples and we obtain the following values:

Wilcoxon rank sum test: $W=4096, p$-value $<2.2 \mathrm{e}-16$, alternative hypothesis: true location shift is not equal to 0 . 
As the $p$-value turns out to be smaller than $2.2 \mathrm{e}-16$, and is less than the 0.05 significance level, we reject the invalid hypothesis. Next, we continue our analysis with the plot in Figure 5. In this figure, 'A' stands for the proximal area and ' $\mathrm{B}$ ' for the occlusal area. We can immediately observe from this plot that in general the SDF penetration is higher in the case of the proximal area A.

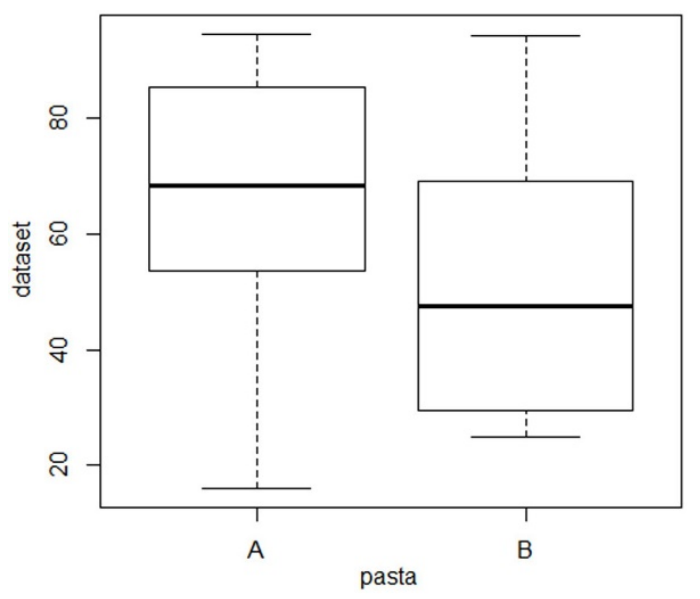

Figure 5 - Statistical analysis plot.

We apply the $\log _{10}$ transform to transform the data into a close to normal distribution because the dependent variable increases more rapidly with increasing independent variable values. We consider $n=32$ since we have 32 measurements for each area and $k=2$ since we have two categories. We plan to test if the means of the groups are equal, the $H_{0}$ hypothesis for this statistical test. We extract the data on each category, and we compute varIntra variable, which is the mean within categories, equal in our case is 435.8386 . Next, we compute the varInter variable, which is the mean between categories, equal in our case with 3406.676. We can compute now the $F$-value for our statistics: $F=$ varInter/varIntra $=7.816371$ and the critical $F$-value, which was $\operatorname{crit} F=q f\left(0.95, d f_{1}=k-1, d f_{2}=n-k\right)=$ 4.170877, with $d f$ being the corresponding data frame and 0.95 the significance level. For taking the decision, we use the following formula if $(F>c r i t F)$ reject $\mathrm{H}_{0}$, else accept $\mathrm{H}_{0}$. Therefore, we reject the $\mathrm{H}_{0}$, and this decision can be interpreted as a statistical recommendation for the more efficient clinical use of SDF penetration in the proximal area.

The average value of the SDF penetration percentage for the proximal area was $65.843 \%$, with a standard deviation of $21.454 \%$, the percentage reaching a maximum of $94.70 \%$. In the case of the percentage of SDF penetration for occlusal area, the average was $51.252 \%$, with a standard deviation of $20.284 \%$ and a maximum of $94.237 \%$ (Table 2; Figure 6).

Analyzing the median value for the proximal area SDF penetration (\%), one observes that in more than $50 \%$ of the measurements the SDF penetration percentage was $68.38 \%$. In the case of the occlusal area SDF penetration, the median value was $47.521 \%$. The values of the upper quartiles (Q3) showed that in $25 \%$ of the measurements, the SDF penetration percentage was higher than $85.89 \%$ for the proximal area SDF penetration $n(\%)$, respectively higher than $69.491 \%$ for the occlusal area SDF penetration (\%) (Table 2; Figure 7).

Table 2 - Descriptive numerical characteristics associated with the studied variables

\begin{tabular}{|c|c|c|c|c|c|c|c|}
\hline & & \multicolumn{3}{|c|}{ Proximal area } & \multicolumn{3}{|c|}{ Occlusal area } \\
\hline & & $\begin{array}{c}\text { Demineralization } \\
{[\mathrm{mm}]}\end{array}$ & $\begin{array}{c}\text { SDF penetration } \\
{[\mathrm{mm}]}\end{array}$ & $\begin{array}{c}\text { SDF penetration } \\
{[\%]}\end{array}$ & $\begin{array}{c}\text { Demineralization } \\
{[\mathrm{mm}]}\end{array}$ & $\begin{array}{c}\text { SDF penetration } \\
{[\mathrm{mm}]}\end{array}$ & $\begin{array}{c}\text { SDF penetration } \\
{[\%]}\end{array}$ \\
\hline \multicolumn{2}{|l|}{ Mean } & 0.302 & 0.188 & 65.843 & 0.390 & 0.198 & 51.252 \\
\hline \multicolumn{2}{|l|}{ Median } & 0.285 & 0.175 & 68.385 & 0.403 & 0.171 & 47.521 \\
\hline \multicolumn{2}{|c|}{ Standard deviation } & 0.128 & 0.092 & 21.454 & 0.127 & 0.100 & 20.284 \\
\hline \multicolumn{2}{|c|}{ Minimum } & 0.076 & 0.052 & 15.960 & 0.142 & 0.042 & 25.000 \\
\hline \multicolumn{2}{|c|}{ Maximum } & 0.553 & 0.433 & 94.700 & 0.647 & 0.428 & 94.273 \\
\hline \multirow{3}{*}{ Percentiles } & 25 & 0.198 & 0.112 & 52.853 & 0.271 & 0.128 & 29.560 \\
\hline & 50 & 0.285 & 0.175 & 68.385 & 0.403 & 0.171 & 47.521 \\
\hline & 75 & 0.393 & 0.242 & 85.890 & 0.510 & 0.278 & 69.491 \\
\hline
\end{tabular}

SDF: Silver Diamine Fluoride.

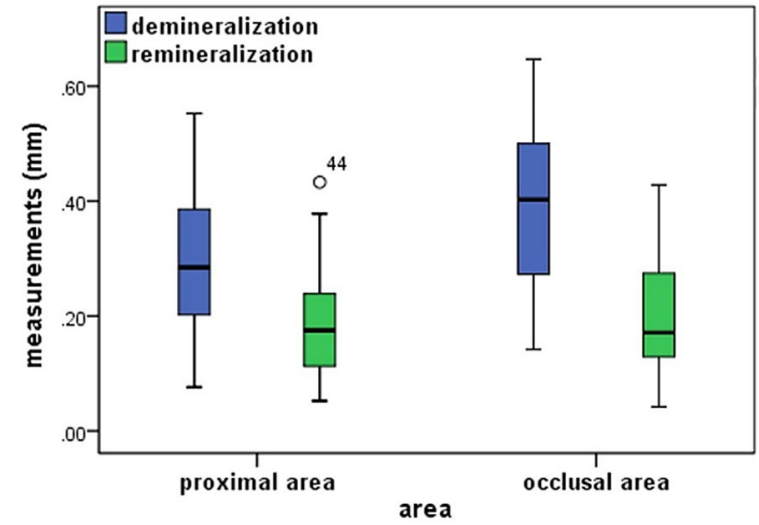

Figure 6-The Box-Plot diagram associated with the measurements for proximal area and occlusal area, respectively, for demineralization and SDF penetration (remineralization), respectively. SDF: Silver Diamine Fluoride.

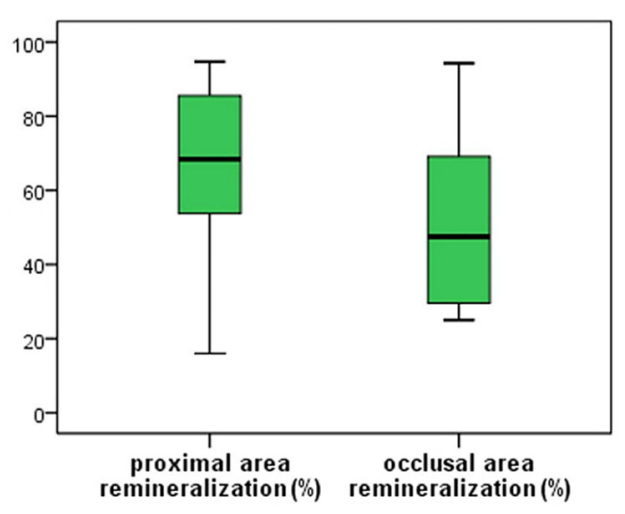

Figure 7 - The Box-Plot diagram associated with the proximal area SDF penetration and occlusal area SDF penetration, respectively. SDF: Silver Diamine Fluoride.

There are significant differences for the measurements done for the proximal area demineralization and the proximal 
area SDF penetration $(t=6.60, p=0.00<0.05)$, respectively for the occlusal area demineralization and the occlusal area SDF penetration $(t=9.74, p=0.000<0.05)$ (Table 3$)$.

Significant differences have been observed between the SDF penetration percentages for the proximal area and the occlusal area $(t=3.161, p=0.003<0.05)$ (Table 4$)$.

In Figures 8-11, some examples of occlusal and proximal measurements of the specific specimens are provided.

Table 3 - T-test for proximal area, respectively occlusal area

\begin{tabular}{|c|c|c|c|c|c|c|c|c|c|}
\hline & & \multicolumn{5}{|c|}{ Paired differences } & \multirow{3}{*}{$t$} & \multirow{3}{*}{$d f$} & \multirow{3}{*}{$\begin{array}{c}\text { Sig. } \\
\text { (2-tailed) }\end{array}$} \\
\hline & & \multirow{2}{*}{ Mean } & \multirow{2}{*}{$\begin{array}{l}\text { Standard } \\
\text { deviation }\end{array}$} & \multirow{2}{*}{$\begin{array}{l}\text { Standard } \\
\text { error of } \\
\text { the mean }\end{array}$} & \multicolumn{2}{|c|}{$\begin{array}{c}95 \% \text { Confidence interval } \\
\text { of the difference }\end{array}$} & & & \\
\hline & & & & & Lower & Upper & & & \\
\hline Pair 1 & $\begin{array}{l}\text { Proximal area demineralization } v s . \\
\text { Proximal area SDF penetration }\end{array}$ & 0.11 & 0.10 & 0.02 & 0.08 & 0.15 & 6.60 & 31 & 0.000 \\
\hline Pair 2 & $\begin{array}{l}\text { Occlusal area demineralization vs. } \\
\text { Occlusal area SDF penetration }\end{array}$ & 0.19 & 0.11 & 0.02 & 0.15 & 0.23 & 9.74 & 31 & 0.000 \\
\hline
\end{tabular}

SDF: Silver Diamine Fluoride.

Table 4 - T-test for the proximal area SDF penetration (\%) and the occlusal area SDF penetration (\%)

\begin{tabular}{|c|c|c|c|c|c|c|c|c|c|}
\hline & & \multicolumn{5}{|c|}{ Paired differences } & \multirow{3}{*}{$t$} & \multirow{3}{*}{$d f$} & \multirow{3}{*}{$\begin{array}{c}\text { Sig. } \\
\text { (2-tailed) }\end{array}$} \\
\hline & & \multirow{2}{*}{ Mean } & \multirow{2}{*}{$\begin{array}{l}\text { Standard } \\
\text { deviation }\end{array}$} & \multirow{2}{*}{$\begin{array}{l}\text { Standard } \\
\text { error of } \\
\text { the mean }\end{array}$} & \multicolumn{2}{|c|}{$\begin{array}{l}95 \% \text { Confidence interval } \\
\text { of the difference }\end{array}$} & & & \\
\hline & & & & & Lower & Upper & & & \\
\hline Pair & $\begin{array}{l}\text { Proximal area SDF penetration (\%) vs. } \\
\text { Occlusal area SDF penetration (\%) }\end{array}$ & 14.5914 & 26.1099 & 4.6156 & 5.1777 & 24.0050 & 3.161 & 31 & 0.003 \\
\hline
\end{tabular}

SDF: Silver Diamine Fluoride.

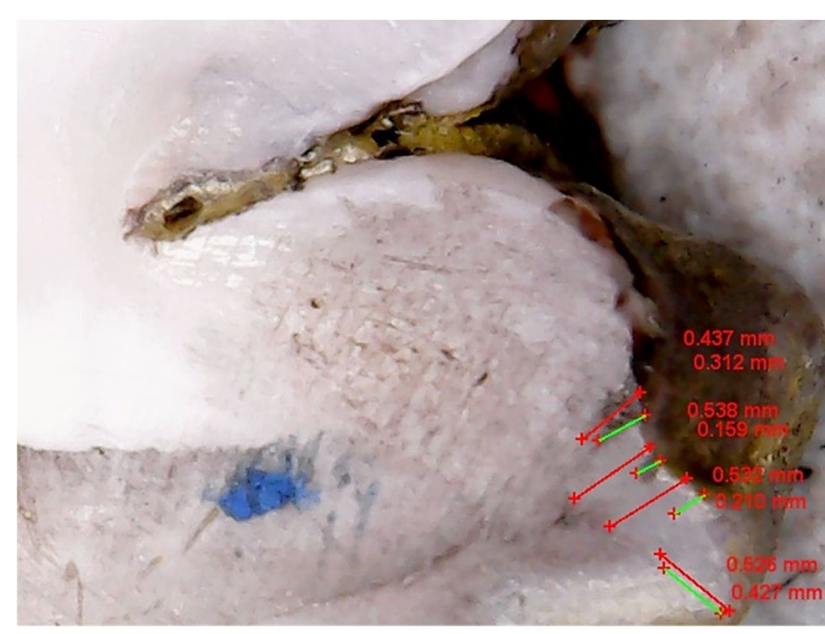

Figure 8 - Specimen No. 3, occlusal area: the demineralized zones - red lines and same areas with Advantage Arrest applied on them (green lines).

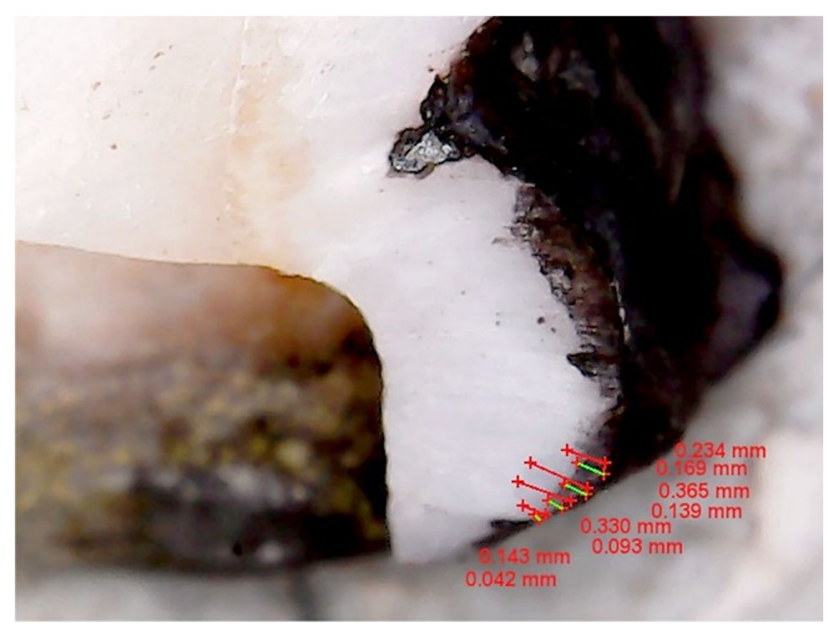

Figure 10 - Specimen No. 8, occlusal area: the demineralized zones - red lines and same areas with Advantage Arrest applied on them (green lines).

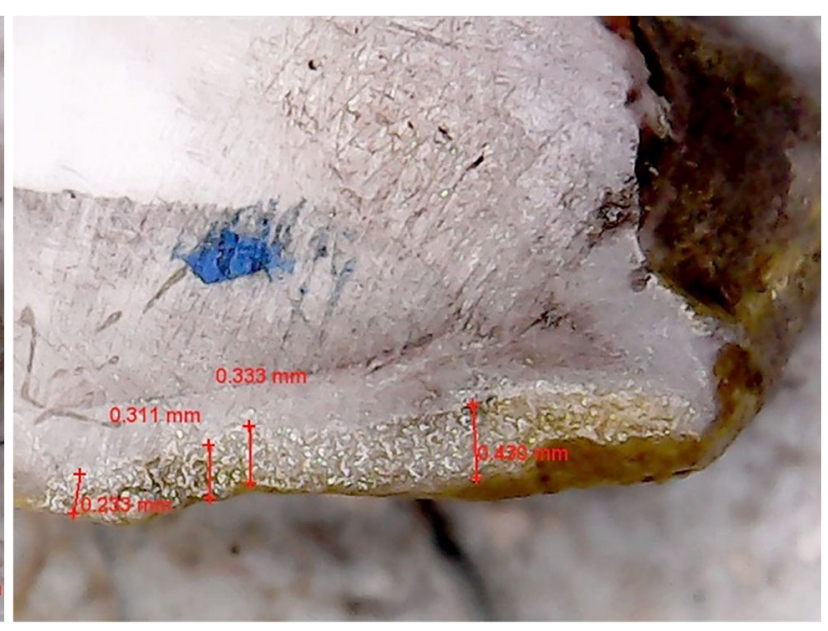

Figure 9 - Specimen No. 3, proximal area: the demineralized zones - red lines and same areas with Advantage Arrest applied on them.

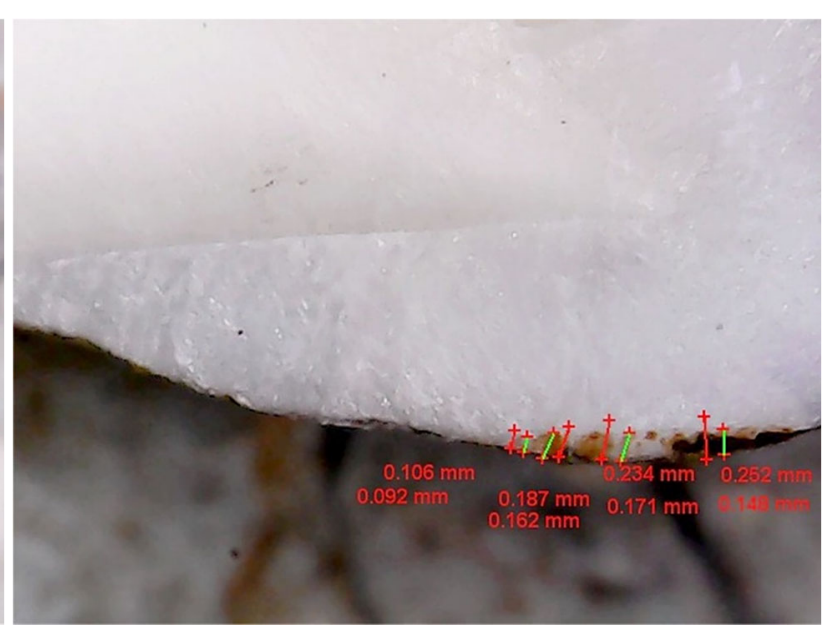

Figure 11 - Specimen No. 8, proximal area: the demineralized zones - red lines and same areas with Advantage Arrest applied on them (green lines). 


\section{ㅁ Discussions}

There is still a difficulty in detecting the early signs of carious lesion, considering the methods for caries detection. The early detection of carious lesions is important for improving the treatment and preventing the major loss of dental structures.

Advantage Arrest's main component is SDF, with the following chemical formula and concentrations: $\mathrm{Ag}\left(\mathrm{NH}_{3}\right)_{2} \mathrm{~F}$, content: $25-27 \% \mathrm{Ag}, 5-6 \%$ fluoride (F), 9-10\% ammonia $\left(\mathrm{NH}_{3}\right)(w / v)$ [13].

This product, having incorporated an antibacterial substance and a remineralizing one increases teeth resistance to acid attack by forming $\mathrm{Ag}$-protein conjugates in decayed tooth's surface. It, also, increases the mineral density by increasing $\mathrm{HA}$ and fluorapatite. $\mathrm{Ag}^{+}$and $\mathrm{F}^{-}$ions penetrate about $25 \mu \mathrm{m}$ into enamel and 50-200 $\mu \mathrm{m}$ into dentin; $\mathrm{F}$ promotes remineralization, and $\mathrm{Ag}$ promotes antimicrobial action. Clinical characteristic and possible disadvantage to take into consideration is the discoloration of the tooth's structure when applied on demineralization and the soft tissues [14-18].

Visual inspection and radiographic examinations are the most often used techniques for caries and structural abnormalities, such as denticles detection; unfortunately, none of these methods is sufficiently sensitive for detecting the first signs of caries. Furthermore, visual inspection and radiographs cannot detect the penetration and efficacy of any antibacterial solutions, which may be applied to stop bacterial metabolism [19].

The dental structures generate a response to inflammatory acid attack through the connective tissue called dental pulp. When the hard dental tissues are not able any more to create a healthy barrier to protect the pulp, it reacts through inflammatory response, through positive T-lymphocytes for the cluster of differentiation (CD)45RO protein, which means that no non-invasive treatments can be fulfilled [20].

To improve detection of early stages in carious lesions, several methods have been tried, such as dental optical coherence tomography (OCT) [21], heterodyne lock-in thermography [22], near-infrared (IR) transillumination and reflectance imaging (in vivo) [23], the most recent one being coherent speckle light scattering pattern [20].

In vivo, the most common used techniques are quantitative light-induced fluorescence, laser-induced fluorescence, fiber optic transillumination [24].

Tooth's structure remineralization was studied with the aid of polarized light microscope, Shah \& Birur detecting " $27.306 \%$ decrease in lesion depth after 10 days of $\mathrm{pH}$ cycling" [25] and by using a fiber optic backscatter spectroscopic sensor, where with Kishen et al. managed to mark initial enamel demineralization and remineralization and to provide useful, significant information that can be used for monitoring changes in a tooth and make comparisons between teeth [26].

It has been shown in clinical and experimental studies that non-cavitary lesions can remineralize if the negative oral environment is altered, using plaque removal technique and $\mathrm{F}$ [27-29].

Other research showed that specific, functionalized AgNPs coated with ethylene glycol (EG) or polyvinylpyrrolidone (PVP) have antibacterial effects on different bacteria; the success depending on the AgNPs dose and of the type of bacteria [30].

In our study, there have been made new attempts in capturing both demineralization and SDF penetration, with a digital optical microscope; the SDF penetration for the proximal surfaces having an easy growth in comparison with SDF penetration on occlusal areas. This difference may appear due to the different morphology of the areas; the proximal area being a smooth zone in comparison with pits and fissures, which may not permit the penetration of antibacterial substances. Being an in vitro study, it is necessary some notifications to be considered; the effectiveness of SDF may be affected by numerous clinical factors, such as tooth surfaces topography, size and shape of gingival papilla, patient's oral hygiene, the bacteria involved in demineralization, the surface's roughness, the enamel structure (normal, hypocalcified) [2, 31-33].

\section{a Conclusions}

SDF is efficient in remineralizing tooth's enamel, and the digital, optical microscope is receptive for evaluation of both enamel demineralization and SDF penetration, in permanent teeth, for proximal and occlusal surfaces. In our study, we succeeded in demonstrating the positive effect of AgNPs on demineralized enamel. In addition to these results, we managed to show differences in remineralizing aspects of occlusal versus proximal enamel surfaces.

\section{Conflict of interests}

The authors declare that they have no conflict of interests. All authors read and approved the final manuscript.

\section{Consent for publication}

Consent for publication of the results of this study has been obtained from all the participants. All the specimens used in this research are extracted teeth for orthodontic purpose and the patients gave their consent for using the teeth as specimens for research purposes.

\section{Acknowledgments}

This study is partially supported by the $\mathrm{PhD}$ grant offered by Victor Babeş University of Medicine and Pharmacy, Timişoara, contract number 3722/03.10.2016.

\section{References}

[1] Silva AVC, Araújo Teixeira JA, Melo Júnior PC, Souza Lima MGS, Oliveira Mota CCB, Lins ECCC, Pereira JRD, Gomes ASL, Targino AGR, Rosenblatt A. Remineralizing potential of nano-silver-fluoride for tooth enamel: an optical coherence tomography analysis. Pesquisa Brasileira em Odontopediatria e Clínica Integrada, 2019, 19:e4002. https:// doi.org/10.4034/PBOCI.2019.191.50

[2] Ritter AV, Boushell LW, Walter R (eds). Sturdevant's art and science of operative dentistry. Elsevier-Mosby, St. Louis, MO, USA, 2019. https://doi.org/10.1016/C2015-0-05603-9

[3] Abou Neel EA, Aljabo A, Strange A, Ibrahim S, Coathup M, Young AM, Bozec L, Mudera V. Demineralization-remineralization dynamics in teeth and bone. Int J Nanomedicine, 2016, 11:4743-4763. https://doi.org/10.2147/IJN.S107624 PMID: 27695330 PMCID: PMC5034904

[4] Abou Neel EA, Bozec L, Knowles JC, Syed O, Mudera V, Day R, Hyun JK. Collagen - emerging collagen based therapies hit the patient. Adv Drug Deliv Rev, 2013, 65(4):429-456. https://doi.org/10.1016/j.addr.2012.08.010 PMID: 22960357 
[5] Bartlett JD. Dental enamel development: proteinases and their enamel matrix substrates. ISRN Dent, 2013, 2013:684607. https://doi.org/10.1155/2013/684607 PMID: 24159389 PMCID: PMC3789414

[6] Paula ABP, Fernandes AR, Coelho AS, Marto CM, Ferreira MM Caramelo F, do Vale F, Carrilho E. Therapies for white spot lesions - a systematic review. J Evid Based Dent Pract, 2017, 17(1):23-38. https://doi.org/10.1016/j.jebdp.2016.10.003 PMID: 28259311

[7] Paris S, Lausch J, Selje T, Dörfer CE, Meyer-Lueckel H. Comparison of sealant and infiltrant penetration into pit and fissure caries lesions in vitro. J Dent, 2014, 42(4):432-438. https://doi.org/10.1016/j.jdent.2014.01.006 PMID: 24444600

[8] Anauate-Netto C, Borelli Neto L, Amore R, Di Hipólito V, D'Alpino PHP. Caries progression in non-cavitated fissures after infiltrant application: a 3-year follow-up of a randomized controlled clinical trial. J Appl Oral Sci, 2017, 25(4):442-454. https://doi.org/10.1590/1678-7757-2016-0633 PMID: 28877284 PMCID: PMC5595118

[9] Oral Health. Advantage Arrest, Silver Diamine Fluoride - new indication. Oral Science, 2017. https://www.oralhealthgroup. com/products/advantage-arrest-silver-diamine-fluoride-newindication/

[10] Mann HB, Whitney DR. On a test of whether one of two random variables is stochastically larger than the other. Ann Math Statist, 1947, 18(1):50-60. https://doi.org/10.1214/aoms/11 77730491

[11] Hollander M, Wolfe AD. Nonparametric statistical methods. $2^{\text {nd }}$ edition, Wiley-Interscience, New York, 1999. https://www. worldcat.org/title/nonparametric-statistical-methods/oclc/647 023625

12] Hinkelmann $\mathrm{K}$, Kempthorne $\mathrm{O}$. Design and analysis of experiments. Volume 1: Introduction to experimental design. Volume 2 Advanced experimental design. $2^{\text {nd }}$ edition, Wiley Series in Probability and Statistics, John Wiley \& Sons, Inc., 2005. https:// doi.org/10.1002/9780470191750 https://doi.org/10.1002/047 1709948

[13] PubChem. Silver Diamine Fluoride: compound summary (CID 161820). National Institutes of Health (NIH), National Library of Medicine (NLM), National Center for Biotechnology Information (NCBI), Bethesda, MD, USA, 2004. https://pubchem.ncbi.nIm. nih.gov/compound/Silver-diammine-fluoride

[14] Elevate Oral Care. Advantage Arrest Silver Diamine Fluoride $38 \%$. http://www.elevateoralcare.com/dentist/AdvantageArrest

[15] Mei ML, Ito L, Cao Y, Li QL, Chu CH, Lo ECM. The inhibitory effects of silver diamine fluorides on cysteine cathepsins. J Dent, 2014, 42(3):329-335. https://doi.org/10.1016/j.jdent. 2013.11.018 PMID: 24316241

[16] Duangthip D, Chen KJ, Gao SS, Lo ECM, Chu CH. Managing early childhood caries with atraumatic restorative treatment and topical silver and fluoride agents. Int J Environ Res Public Health, 2017, 14(10):1204. https://doi.org/10.3390/ijerph141 01204 PMID: 28994739 PMCID: PMC5664705

[17] Yee R, Holmgren C, Mulder J, Lama D, Walker D, van Palenstein Helderman W. Efficacy of silver diamine fluoride for arresting caries treatment. J Dent Res, 2009, 88(7):644-647. https://doi.org/10.1177/0022034509338671 PMID: 19641152

[18] Corrêa JM, Mori M, Sanches HL, da Cruz AD, Poiate E Jr Poiate IAVP. Silver nanoparticles in dental biomaterials. Int J Biomater, 2015, 2015:485275. https://doi.org/10.1155/2015/ 485275 PMID: 25667594 PMCID: PMC4312639

[19] Deva V, Mogoantă L, Manolea H, Pancă OA, Vătu M, Vătăman M. Radiological and microscopic aspects of the denticles. Rom $J$ Morphol Embryol, 2006, 47(3):263-268. PMID: 17308686
[20] Manolea H, Mogoantă L, Mărgăritescu Cl, Deva V, Şurlin P, Caraivan $\mathrm{O}$. Immunohistochemical aspects of the evaluation of the inflammatory answer of the dental pulp. Rom J Morphol Embryol, 2009, 50(2):207-212. PMID: 19434312

[21] Hsieh YS, Ho YC, Lee SY, Chuang CC, Tsai JC, Lin KF, Sun CW. Dental optical coherence tomography. Sensors (Basel), 2013, 13(7):8928-8949. https://doi.org/10.3390/s130708928 PMID: 23857261 PMCID: PMC3758630

[22] Wang F, Liu JY, Mohummad O, Wang XC, Wang Y. Heterodyne lock-in thermography of early demineralized in dental tissues. Infrared Phys Technol, 2017, 87:83-90. https://doi.org/10.1016/ j.infrared.2017.10.001

[23] Simon JC, Lucas SA, Staninec M, Tom H, Chan KH, Darling CL, Cozin MJ, Lee RC, Fried D. Near-IR transillumination and reflectance imaging at 1,300 $\mathrm{nm}$ and $1,500-1,700 \mathrm{~nm}$ for in vivo caries detection. Lasers Surg Med, 2016, 48(9):828-836. https://doi.org/10.1002/lsm.22549 PMID: 27389018 PMCID: PMC5495016

[24] Olivan SRG, Deana AM, Pinto MM, Sfalcin RA, Fernandes KPS, Mesquita-Ferrari RA, Prates RA, Bussadori SK. Diagnosis of occlusal caries lesions in deciduous molars by coherent light scattering pattern speckle. Photodiagnosis Photodyn Ther, 2017, 18:221-225. https://doi.org/10.1016/j.pdpdt.2017.03.004 PMID: 28300725

[25] Shah SP, Birur PN. Polarized light microscopic evaluation of remineralization by casein phosphopeptide-amorphous calcium phosphate paste of artificial caries-like lesion: an in vitro study. J Indian Acad Oral Med Radiol, 2015, 27(4):559-564. https:// doi.org/10.4103/0972-1363.188761

[26] Kishen A Shrestha A, Rafique A. Fiber optic backscatter spectroscopic sensor to monitor enamel demineralization and remineralization in vitro. J Conserv Dent, 2008, 11(2):63-70. https://doi.org/10.4103/0972-0707.44053 PMID: 20142887 PMCID: PMC2813093

[27] de Amorim RG, Leal SC, Bezerra ACB, de Amorim FPLG de Toledo OA. Association of chlorhexidine and fluoride for plaque control and white spot lesion remineralization in primary dentition. Int J Paediatr Dent, 2008, 18(6):446-451. https:// doi.org/10.1111/j.1365-263X.2008.00914.x PMID: 18489576

[28] Gao SS, Zhang S, Mei ML, Lo ECM, Chu CH. Caries remineralisation and arresting effect in children by professionally applied fluoride treatment - a systematic review. BMC Oral Health, 2016, 16:12. https://doi.org/10.1186/s12903-016-01 71-6 PMID: 26831727 PMCID: PMC4736084

[29] Manarelli MM, Delbem ACB, Lima TMT, Castilho FCN, Pessan JP. In vitro remineralizing effect of fluoride varnishes containing sodium trimetaphosphate. Caries Res, 2014, 48(4): 299-305. https://doi.org/10.1159/000356308 PMID: 24526110

[30] Popescu EL, Bălăşoiu M, Cristea OM, Stoica AE, Oprea OC, Vasile BŞ, Grumezescu AM, Băncescu G, Busuioc CJ, Mogoşanu GD, Streba CT, Mogoantă L. Study of antimicrobial effects of functionalized silver nanoparticles. Rom J Morphol Embryol, 2019, 60(3):939-946. PMID: 31912107

[31] Hu JCC, Chun YHP, Al Hazzazzi T, Simmer JP. Enamel formation and amelogenesis imperfecta. Cells Tissues Organs, 2007, 186(1):78-85. https://doi.org/10.1159/000102683 PMID: 17627121

[32] Tyagi SP, Garg P, Sinha DJ, Singh UP. An update on remineralizing agents. J Interdiscip Dent, 2013, 3(3):151158. https://doi.org/10.4103/2229-5194.131200

[33] Sapir S, Shapira J. Clinical solutions for developmental defects of enamel and dentin in children. Pediatr Dent, 2007, 29(4): 330-336. PMID: 17867401

\section{Corresponding author}

Emanuela Lidia Crăciunescu, Lecturer, MD, PhD, Department of Prostheses Technology and Dental Materials, Faculty of Dental Medicine, Victor Babeş University of Medicine and Pharmacy, 2 Eftimie Murgu Square, 300041 Timişoara, Romania; Phone +40744-616 009, e-mail: emanuelapetrescu@yahoo.com 